\title{
Developing a Teaching Material Oriented to Science and Technology and Local Wisdom in Wetland Environment
}

\author{
Zainuddin, Helman Ari Afnizar, Mastuang, Misbah \\ Physics Education Program, Faculty of Teacher Training and Education \\ Universitas Lambung Mangkurat \\ Banjarmasin, Indonesia \\ zainuddin_pfis@ulm.ac.id, Ariafnizar@gmail.com,mastuang_pfis@ulm.ac.id, misbah_pfis@ulm.ac.id
}

\begin{abstract}
This research was based on science lesson that had not been linked with science and technology and local wisdom of Barito Kuala society. Therefore, research that aimed to describe the feasibility of teaching materials of vibration and wave of science and technology insight and local wisdom in the wetland environment. Specific objectives of this study were to describe: (1) validity of teaching materials of IPA, (2) practicality of teaching materials of science, $(3)$ the effectiveness of teaching materials of science. This research type was research and development with the ADDIE model. The subjects of the experiment were students of SMP Negeri 4 Alalak Barito Kuala which amounted to 31 students. Data obtained through the module validation sheet, RPP observation sheet, student learning result test. The result of the research shows that: (1) the validity of teaching materials developed well categorized, (2) the practicality of teaching materials based on the implementation of RPP categorized very well, (3) the effectiveness of teaching materials categorized IPA is being seen from the test of student learning outcomes in the form of pretest and posttest then calculated using the $\mathrm{N}$-gain test. The conclusion obtained was that the teaching materials of vibration and science waves of science and technology and local wisdom are suitable for learning.
\end{abstract}

Keywords-Teaching materials, science and technology, local wisdom, wetlands.

\section{INTRODUCTION}

Science learning plays a very important role in the development of science and technology and in terms of building the character of students. This condition requires learning of science that has good quality in order to be able to follow the development of science and technology today. The use of learning technology tools that can improve students' understanding of science concepts is one of the keys to success in science education [1]. Therefore, the use of relevant learning devices as learning technology products has an important role in science learning activities, especially physics.

Physics will be more meaningful if there is a link between the material taught with daily activities in an environment where students live as learning tools for students [2]. Material knowledge of physics with local identity or wisdom around the place where students live, not only aims to make it easier for students to understand physics material but also so that students are more familiar with the surrounding culture which might begin to be replaced with external culture.

Indonesia is a unitary state consisting of islands with each region having its own local wisdom [3], one of which is the area of Barito Kuala Regency which is part of the Province of South Kalimantan. The community in Barito Kuala Regency is still very strong with its local culture, one of which is important music which is local customs and wisdom that characterizes the area.

Based on observations made at Alalak 4 Public Middle School, learning in science, especially physics, which has been running so far has not yet been linked to learning material with the cultural identity of the Barito Kuala region, the lack of books or teaching materials as teaching materials used for intermediaries between science learning materials with science and technology and local wisdom.

Therefore, the solution that is believed to be able to overcome the problem in SMP Negeri 4 Alalak is the development of teaching materials in which not only IPA material, especially physics, but also links between science materials and science and technology and the local wisdom of the area. This is so that students can understand the material of science that is associated with science and technology and local wisdom in Batola and can gain learning experience directly with the conditions around the daily environment. Based on the results of previous studies, it was found that science-based learning modules based on Science, environment, technology, and society (Salingtemas) of students' learning outcomes after learning using high-class modules [4]. Each region has each characteristic that can be taken in the learning process in class [5], both as a source of learning and as an object of problems that can improve student learning outcomes due to relevance to subjects with the everyday environment. Insight into the issue of wetlands at the time of learning will also add to the knowledge of local wisdom of students towards their environment and can improve student learning outcomes [5][6]. Science subjects, especially the eighth-grade junior high school physics there are vibration and wave material that can be related to the condition of wetlands in Barito Kuala. 
Based on the problems described above, the authors conducted a study with the title, namely "Development of IPA Learning Materials Vibration and Wave of Science and Technology and Local Wisdom in Wetland Environment." The general objective of this study is to describe the feasibility of vibration science and learning materials with science and technology insight and local wisdom in the wetland environment.

\section{METHOD}

This type of research is development research. The product developed in this study is in the form of teaching material which contains vibration material and waves of science and technology insight and local wisdom in the wetland environment. The development model used in this study is the ADDIE model (Analyze, Design, Development, Implementation, Evaluation).

The subjects in this study were vibrational science teaching materials and waves of science and technology insight and local wisdom in the wetland environment. The subjects of this research trial were class VIII B of SMP Negeri 4 Alalak in the 2016-2017 school year.

Data collection techniques used in this study were validation sheets, lesson plan implementation sheets, and learning outcomes tests. The validation sheet is used as an evaluation of the validity of teaching material developed and assessed by three validators, namely two academic validators and one practitioner validator. Then adjusted to the validation criteria of teaching material [7]. The implementation sheet of RPP (Learning Implementation Plan) is used to measure and know the practicality of teaching material that is assessed by two observers when learning takes place, then analyzed using criteria [8]. Tests of student learning outcomes in the form of pretest and posttest are used to measure how effective the use of teaching materials developed when the teaching and learning process takes place. Then analyzed using N-gain [9].

\section{RESULT AND DISCUSSION}

The product developed in this study is science teaching material on the subject of vibrations and waves. The teaching material developed is insightful science and technology and local wisdom in the wetland environment. In the teaching material, science and technology in question is an important musical instrument that plays the same way as the guitar, namely, the local wisdom in the Batola area is important traditional music that can be related to vibration and wave subjects while the wetlands in this study are school environments most research sites in the Batola area are areas surrounded by rivers and swamps.

This teaching material consists of front cover, competency standards, and basic competencies, concept maps, description of vibration and wave material, science scientists, science information, technology columns, science, and technology columns, sample questions, let's try, summarize, review comprehension, and bibliography. The distinctive feature of this teaching material is the existence of insightful material with science and technology and local wisdom so that students gain knowledge about the technology and local wisdom of the area. The results obtained in the study include validity, practicality, and effectiveness.

\section{A. The validity of Teaching Material}

The validity of teaching material is measured by a validation assessment sheet. The results of the teaching material validation can be seen from several aspects, namely content, presentation, language, graphics, insight, and benefits/uses. From this aspect, the average per aspect has been obtained, which is equal to 3.00 with a good category. The overall validity of the teaching material shows that the developed teaching material is good based on the assessment of academics and practitioners. Reference [8] states that an instrument is said to be valid if it reveals data from variables that are properly examined. Validation is aimed more at knowing and measuring whether teaching material is still in accordance with the development of needs and conditions that are currently running. These results indicate that the science material developed is feasible and can be used in the pilot phase at school.

\section{B. The practicality of the Teaching Material}

Practically or not a learning device developed is seen from the implementation of the lesson plan. The results of observations on the implementation of the RPP were obtained that both in meetings I and II, the percentage of implementation of the RPP was very well categorized with scores of $88.12 \%$ and $91.12 \%$. The practicality of teaching material is shown by the ease of vibration teaching material, and the wave of science and technology insight and local wisdom implemented in the classroom and used by students. A product is said to be practical if the product assumes that it can be used. The results of the analysis of the implementation of the RPP show that the science materials developed have been practical to use because the results of the implementation of RPP are categorized very well.

\section{The effectiveness of the Teaching Material}

The effectiveness of teaching materials developed can be found through student learning outcomes tests [10]. The effectiveness of teaching material in this study was measured by giving written tests given before the pretest and at the end of the lesson (posttest) consisting of 5 essay questions calculation of pretest and posttest test of student learning outcomes using the normalized gain equation (N-Gain). Based on the calculation results obtained by the gain value of 0.35 with the medium category, then the vibration science teaching material and waves of science and technology insight and local wisdom in the wetland environment were declared effective to use. This is in line with several studies which state that wetland-based learning and local wisdom-based learning are effectively used in the learning process and can improve student learning outcomes [3][5][6]. Learning that links the concepts/principles of science with its application in the surrounding environment, makes students become motivated in learning [11]. Students not only learn their knowledge but 
also can apply it in daily life so that the learning process obtained by students becomes more meaningful [12]. This has an effect on student learning outcomes [13].

\section{CONCLUSION}

Science and technology teaching materials with the knowledge of science and technology and local wisdom in the vibration and wave material developed are feasible to be used in the learning process. This is supported by the following findings: 1) the overall validity of the teaching material developed in the category of valid, 2) the practicality of teaching material measured based on the implementation of the lesson plan having good criteria, and 3) the effectiveness of teaching material developed in the medium category.

\section{REFERENCES}

[1] A. Isman, H. Yaratan, and H. Caner, "How technology is integrated into science education in a developing country: north cyprus case," The Turkish Online Journal of Education Technology, vol. 6, no.3, 2007.

[2] S. Hartini, S. Firdausi, Misbah, and N. F. Sulaeman, "The development of physics teaching materials based on local wisdom to train Saraba Kawa characters," J. Pendidik. IPA Indonesia., vol. 7, no. 2, pp. 130 $137,2018$.

[3] D. Oktaviana, S. Hartini, and M. Misbah, "Pengembangan Modul Fisika Berintegrasi Kearifan Lokal Membuat Minyak Lala Untuk Melatih Karakter Sanggam," Berk. Ilm. Pendidik. Fis., vol. 5, no. 3, pp. 272 285, 2017.

[4] D. Y. K.Sari, S. Wahyuni, and B. Supriyadi, "Pengembangan modul pembelajaran IPA berbasis salingtemas (sains, lingkungan, teknologi, masyarakat) di SMP,”Jurnal Pembelajaran Fisika, vol. 5, no. 3, pp. 218$225,2016$.

[5] M. Selvia, M. Arifuddin, and A. I. Mahardika, "Pengembangan Bahan Ajar Fisika SMA Topik Fluida Berorientasi Masalah Lahan Basah Melalui Pendekatan Contextual Teaching And Learning (CTL)," Berkala Ilmiah Pendidikan Fisika, vol. 5, no. 2, pp. 213-222, 2017.

[6] N. Aini, Z. Zainuddin, and A.I. Mahardika, "Pengembangan Materi ajar IPA menggunakan model pembelajaran kooperatif berorientasi lingkungan lahan basah," Berkala Ilmiah Pendidikan Fisika, vol. 6, no. 2, 2018.

[7] E. P. Widoyoko, Evaluasi program pembelajaran. Yogyakarta: Pustaka Pelajar, 2013.

[8] S. Arikunto, Prosedur penelitian suatu pendekatan praktik, Jakarta: Rineka Cipta, 2010.

[9] R. R. Hake, "Interactive-Engagement Versus Traditional Methods: A Six-Thousand-Student Survey of Mechanics Test Data for Inductory Physics Courses,” Am. J. Phys., vol. 66, no. 1, pp. 65-74, 1998.

[10] J. V. Akker, Design Approaches and Tools in Education and Training. Dodrecht: Kluwer Academic Publisher, 1998.

[11] M. Wati, S. Hartini, M. Misbah, and R. Resy, "Pengembangan Modul Fisika Berintegrasi Kearifan Lokal Hulu Sungai Selatan,” J. Inov. Dan Pembelajaran Fis., vol. 4, no. 2, pp. 157-162, 2017.

[12] S. Hartini, S. Firdausi, Misbah, and N. F. Sulaeman, "The development of physics teaching materials based on local wisdom to train Saraba Kawa characters," J. Pendidik. IPA Indonesia., vol. 7, no. 2, pp. 130 137, 2018.

[13] S. Hartini, M. Misbah, H. Helda, and D. Dewantara, "The effectiveness of physics learning material based on South Kalimantan local wisdom," in AIP Conference Proceedings, vol. 1868, 2017. 